\title{
Selection of Detergent Product Brands Using the Fuzzy Analytical Hierarchy Process Method
}

\author{
*Sudin Saepudin ${ }^{1}$, Adhitia Erfina ${ }^{2}$, Falentino Sembiring ${ }^{3}$, Arny Lattu ${ }^{4}$, \\ Sihabudin 5 \\ ${ }^{1}$ Nusa Putra University, Sukabumi, Indonesia \\ ${ }^{2}$ Nusa Putra University, Sukabumi, Indonesia \\ ${ }^{3}$ Nusa Putra University, Sukabumi, Indonesia \\ ${ }^{4}$ Nusa Putra University, Sukabumi, Indonesia \\ ${ }^{5}$ Nusa Putra University, Sukabumi, Indonesia \\ *Corresponding author. E-mail: sudin.saepudin@nusaputra.ac.id
}

\begin{abstract}
Entrepreneurs continue to improve their products, such as detergents, because of the existence of an era like today. According to Toko Rini's research, there are difficulties in selecting which detergent to use. As a result, the authors investigated the value of Decision Support Systems in assisting buyers of detergent brand products to decide which product brands best meet their demands and criteria. Price, Wangi, Content, Quality, and Packaging are utilized factors. The Fuzzy Analytical Hierarchy Process approach was employed in this study. The Fuzzy AHP technique calculation results show that the alternative (Daia) has the ideal weight value of 1.5960 compared to the other alternatives. As a result, it is safe to say that Daia is the most excellent detergent brand.
\end{abstract}

Keywords: F-AHP, Criteria, SPK.

\section{INTRODUCTION}

In the current day of globalization, when entrepreneurs are constantly updating their products, they utilize detergents, resulting in a plethora of laundry soap brand items that compete in the market, both domestic and foreign products. For people who have limited knowledge of laundry soap brand products yet wish to use them, the large variety of detergent brand products can be bewildering.

The issues raised above demonstrate the value of a Decision Support System in assisting buyers of laundry soap brand products in selecting product brands that meet their demands and criteria. According to an earlier study, the PRL brand is ranked 1 with a weight of 0.33 , and brand $C$ is ranked 2 with 0.22 in a decision-making department store supplier selection utilizing the Fuzzy AHP method [1].

According to Toko Rini's research, various issues highlight the significance of a Decision Support System in selecting detergents to assist customers in making more informed decisions about the goods they will use.

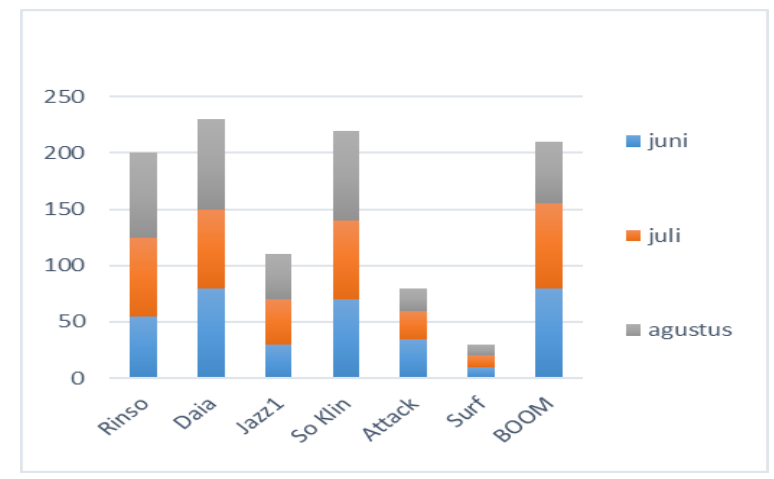

Figure 1. Graph of Purchase Percentage of Detergent Product Brands at Rini's Store

This study demonstrated the value of a Decision Support System in assisting buyers of detergent brand products in making product brand selections based on their needs and criteria. The Fuzzy Analytical Hierarchy Process method was employed in this study as a decision support system. 


\section{LITERATURE REVIEW}

\subsection{Detergent}

The term "detergent" refers to a product used to clean clothing. Apart from washing, detergents can help guard against germs and give clothes a pleasant odor. Detergents come in a variety of forms, including powder and liquid.

\subsection{Brand}

A brand is a symbol, sign, design, or a mix of these three elements that are shown as the identity of numerous sellers to function as a market differentiator. Differences between brands are regarded as symbolic and emotional representations linked to the performance of a product bearing that brand in the future.

\subsection{Fuzzy Analytical Hierarchy Process (Fuzzy AHP)}

One way for measuring how vital a Decision Support System is in identifying the optimal detergent product brand is to use fuzzy AHP [2]. Chang created Fuzzy AHP in 1996 as a version of the AHP (Analytical Hierarchy Process) technique, which describes complicated multi-factor or multicriteria situations as a hierarchy, making them appear more structured and systematic. The Fuzzy AHP technique can be argued to be better since it can address the AHP method's flaws, such as issues with criteria that have more subjective qualities.
Fuzzy AHP [2] is one method for determining how vital a Decision Support System is in determining the best detergent product brand. In 1996, Chang developed Fuzzy AHP as a variant of the AHP (Analytical Hierarchy Process) technique, which uses a hierarchy to represent complex multifactor or multi-criteria situations, making them appear more structured and systematic. The Fuzzy AHP methodology might be superior because it addresses the AHP method's weaknesses, such as concerns with subjective criteria.

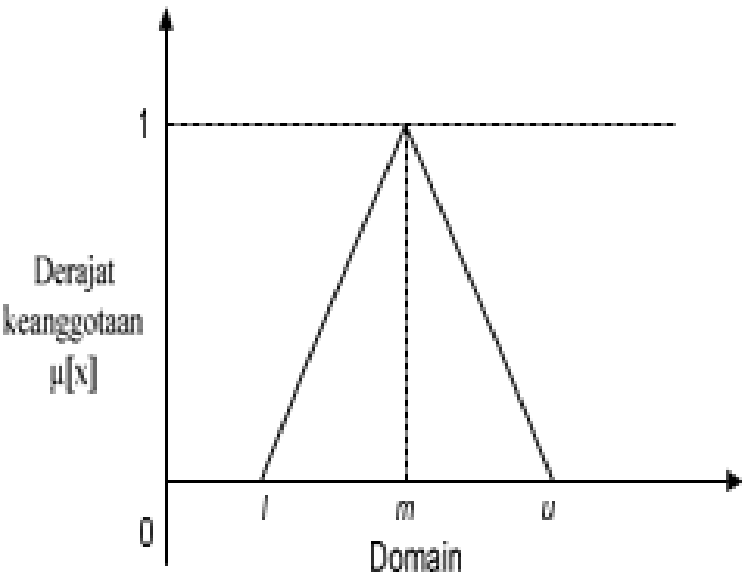

Figure 2. Triangle Membership Function [3] [4]

Except for the intensity of importance, it defines the AHP intensity value as a fuzzy triangular scale that divides each fuzzy set by two (2). (1) Chang's fuzzy triangular scale can be seen in the table below.

Table 1. Triangle Fuzzy Value Scale

\begin{tabular}{|c|c|c|}
\hline AHP Scale & Fuzzy Scale & Fuzzy Scale Inverse \\
\hline 1 & $1=(1,1,1)=$ if diagonal $(1,1,3)=$ other & $(1 / 3,1 / 1,1 / 1)$ \\
\hline 3 & $3=(1,3,5)$ & $(1 / 5,1 / 3,1 / 1)$ \\
\hline 5 & $5=(3,5,7)$ & $(1 / 7,1 / 5,1 / 3)$ \\
\hline 7 & $7=(5,7,9)$ & $(1 / 9,1 / 7,1 / 5)$ \\
\hline 9 & $9=(7,9,9)$ & $(1 / 9,1 / 9,1 / 7)$ \\
\hline 2 & $2=(1,2,4)$ & $(1 / 4,1 / 2,1 / 1)$ \\
\hline 4 & $4=(2,4,6)$ & $(1 / 6,1 / 4,1 / 2)$ \\
\hline 6 & $6=(4,6,8)$ & $(1 / 8,1 / 6,1 / 4)$ \\
\hline 8 & $8=(6,8,9)$ & $(1 / 9,1 / 8,1 / 6)$ \\
\hline
\end{tabular}

The steps for completing the F-AHP are as follows [5] [4]:

1) Determine the comparison of paired matrices between criteria using the TFN scale as given in Table 1 and create a hierarchical structure of the problem to be solved.

2) Determine the priority fuzzy $(\mathrm{Si})$ synthesis value with the formula, 


$$
S i=\sum_{j=1}^{m} M_{i}^{j} x \frac{1}{\sum_{i=1}^{n} \sum_{j=1}^{m} M_{i}^{j}}
$$

Where:

$$
\sum_{j=1}^{m} M_{i}^{j} \sum_{j=1}^{m} l j, \sum_{j=1}^{m} m j, \sum_{j=1}^{m} u j
$$

Whereas:

$$
\frac{1}{\sum_{j=1}^{n} \sum_{j=1}^{m} M_{i}^{j}}=\frac{1}{\sum_{i=1}^{n} u i, \sum_{i=1}^{n} m i, \sum_{i=1}^{n} l i}
$$

3) Calculate the value of the vector $(\mathrm{V})$ and the Defuzzification Ordinate (d'). If the results for each fuzzy matrix are obtained,

$$
\begin{aligned}
M_{i} M_{2} \geq M_{1}\left(M_{2}\right. & =\left(l_{2}, m_{2}, u_{2}\right) \text { dan } M_{2} \\
& =\left(l_{1}, m_{1}, u_{1}\right)
\end{aligned}
$$

The vector value can then be expressed as follows:

$V(M 2 \geq M 1)=$

$\sup \left[\min \left(\mu M_{1}(x), \min \left(\mu M_{2}(y)\right)\right)\right]$

Something similar to the graph in the image below:

$$
\begin{aligned}
& V(M 2 \geq M 1)=f(x)= \\
& \left\{1, \quad \text { if } m_{2} \geq\right. \\
& m_{1}, 0, \quad \text { if } l_{1} \geq \\
& \mu_{2}, \frac{l_{1}-\mu_{2}}{\left(m_{2}-\mu_{2}\right)-\left(m_{1}-l_{1}\right)}
\end{aligned}
$$

If the fuzzy value's outcome is bigger than $\mathrm{k}, \mathrm{Mi}$ $(\mathrm{i}=1,2, \mathrm{k})$, the vector value is defined as follows: Something similar to the graph in the image below:

$V\left(M \geq M_{1}, M_{2, \ldots . . .} M_{k}\right)=V\left(M \geq M_{1}\right)$ dan

$V\left(M \geq M_{2}\right) \operatorname{dan} V\left(M \geq M_{K}\right)=V\left(M \geq M_{1}\right)$

Assume that,

$d^{\prime}(A i)=V(S i \geq S k)$

For $\mathrm{k}=1,2, \ldots, \mathrm{n} ; \mathrm{k} \neq \mathrm{I}$, The vector weight value is then obtained.

$W^{\prime}=\left(d^{\prime}\left(A_{1}\right), d^{\prime}\left(A_{2}\right), \ldots, d^{\prime}\left(A_{n}\right)\right)^{\mathrm{T}}$

Where $A_{i}=1,2, . ., n$ is a decision element

4) Weight values of fuzzy vectors are normalized $(\mathrm{W})$ The normalized value of the vector weight is as follows after normalization of equation (7): The vector weight value is then obtained.

$W=\left(d^{\prime}\left(A_{1}\right), d\left(A_{2}\right), \ldots, d^{\prime}\left(A_{n}\right)\right)^{\mathrm{T}}$

Where $\mathrm{W}$ is non-fuzzy.

\section{RESEARCH METHODS}

\subsection{Method of collecting data}

Primary and secondary data were employed as data sources [2].

\section{2. primary data}

These are data collected directly from the field by handing out a list of questions/questionnaires and conducting direct interviews with resource people. The information gathered will be analyzed, particularly in interpreting or explaining the meaning of the data. Five criteria were determined based on the findings of the observations: price, fragrance, substance, quality, and packaging.

\subsection{Secondary Data}

Is written information that has not been gathered directly from the field. It could be in study findings, scholarly articles, or other formats. This secondary data is gathered through literature studies, which entails reading, studying, and interpreting literature sources related to the research topic, in this case, the detergent product brand that the Sukabumi community most requires.

While this study's data collection methodologies were carried out by:

1) A list of questions/questionnaires, i.e., gathering data and information on informants using a written interview sheet to elicit answers or responses from respondents about the research topic.

2) An interview is a question-and-answer strategy used with research participants to collect data from a list of questions/questionnaires and secondary data gained by holding direct questions and answers with research participants, such as detergent product users and merchants. goods containing detergent

\subsection{Results and Discussion}

\subsubsection{Criteria Data}

The criteria and data utilized in the detergent brand selection were collected after questioning the shop owner, as shown in Table 2. 
Table 2. Value of Criteria and Sub Criteria

\begin{tabular}{|l|}
\hline \multicolumn{1}{|c|}{ Criteria } \\
\hline Price \\
\hline Fragrant \\
\hline Contents \\
\hline Quality \\
\hline Packaging \\
\hline
\end{tabular}

The F-AHP approach is used to solve the problem after the criteria data has been acquired.

\subsubsection{Preparation of Evaluation Criteria}

\subsubsection{Compile a pairwise comparison matrix}

The procedure of determining criteria is carried out, in this case, using the pairwise comparison matrix of the fuzzy triangular numbers that have been obtained. As a result, it can serve as a benchmark for each triangular fuzzy image; for example, if the triangular fuzzy number is not feasible, the matrix determination in decimal can be 1.00 .

Table 3. Conversion results of triangular fuzzy numbers in decimal.

\begin{tabular}{|c|c|c|c|c|c|}
\hline Criteria & Price & Fragrant & Contents & Quality & Packaging \\
\hline Price & 1.00 & 3.00 & 2.00 & 0.20 & 2.00 \\
\hline Fragrant & 0.33 & 1.00 & 3.00 & 0.50 & 2.00 \\
\hline Contents & 0.50 & 0.33 & 1.00 & 0.20 & 2.00 \\
\hline Quality & 5.00 & 2.00 & 5.00 & 1.00 & 5.00 \\
\hline Packaging & 0.50 & 0.50 & 0.50 & 0.20 & 1.00 \\
\hline
\end{tabular}

\subsubsection{Calculating the priority vector for the main criteria}

In this step, each column that contains the benchmarks of the fuzzy triangular is summed, as in Table 4.

Table 4. The results of the sum of each column of fuzzy triangular benchmark

\begin{tabular}{|c|c|c|c|c|c|}
\hline Criteria & Price & Fragrant & Contents & Quality & Packaging \\
\hline Price & 1.00 & 3.00 & 2.00 & 0.20 & 2.00 \\
\hline Fragrant & 0.33 & 1.00 & 3.00 & 0.50 & 2.00 \\
\hline Contents & 0.50 & 0.33 & 1.00 & 0.20 & 2.00 \\
\hline Quality & 5.00 & 2.00 & 5.00 & 1.00 & 5.00 \\
\hline Packaging & 0.50 & 0.50 & 0.50 & 0.20 & 1.00 \\
\hline Amount & 7.33 & 6.83 & 11.50 & 2.10 & 12.00 \\
\hline
\end{tabular}

\subsubsection{Determination of the priority vector of each row}

Table 5. Results of determining priority vectors for each row
\begin{tabular}{|l|c|c|c|c|c|c|c|}
\hline \multicolumn{1}{|c|}{ Criteria } & Price & Fragrant & Contents & Quality & Packaging & Amount & $\begin{array}{c}\text { Priority } \\
\text { Vector }\end{array}$ \\
\hline Price & 0.14 & 0.44 & 0.17 & 0.10 & 0.17 & 1.01 & 0.20 \\
\hline Fragrant & 0.05 & 0.15 & 0.26 & 0.24 & 0.17 & 0.86 & 0.17 \\
\hline
\end{tabular}

In this phase, each row is added together, and the total of each table cell is divided by the total of its columns. Meanwhile, the number of competency qualities is divided by the total sum of each row.
Table 5. Results of determining priority vectors for each row 


\begin{tabular}{|l|l|l|l|l|l|l|l|} 
Contents & 0.07 & 0.05 & 0.09 & 0.10 & 0.17 & 0.47 & 0.09 \\
\hline Quality & 0.68 & 0.29 & 0.43 & 0.48 & 0.42 & 2.30 & 0.46 \\
\hline Packaging & 0.07 & 0.07 & 0.04 & 0.10 & 0.08 & 0.36 & 0.07 \\
Amount & 1.00 & 1.00 & 1.00 & 1.00 & 1.00 & 5.00 & 1.00 \\
\hline
\end{tabular}

\subsubsection{Calculating the $C I$ and $C R$. consistency indices}

The final step is to calculate the CI and CR, which will be used as variables to decide whether the intended matrix design is consistent enough; if not, the matrix must be redesigned until it is.

Using the formula [6], calculate the consistency index $(\mathrm{CI})$ :

$C I=\frac{\Lambda \max -n}{n-1}$

Calculating Consistency Ratio (CR) with the following formula:

$\mathrm{CI}=\frac{1.115-5}{5-1}=-0.972$
$\mathrm{CR}=C I / R I \frac{-0.972}{1.12}=-0.868$

$\mathrm{RI}=$ Random Index

Because $\mathrm{CR}<=0.1$, then the matrix is said to be quite consistent.

\subsubsection{Calculating the Mean Geometric Value}

Calculate the geometric mean in each row, or the root $\mathrm{n}$ of the multiplication of the values in the cells in that row of the matrix, to determine the level of relevance. The letter $\mathrm{n}$ denotes the number of criteria/alternatives. The results of the geometric mean can be shown in Table 6 .

Table 6. The Geometric mean value

\begin{tabular}{|l|c|c|c|}
\hline \multicolumn{4}{|c|}{ Geometric mean } \\
\hline \multicolumn{1}{|c|}{ Criteria } & $\mathrm{I}$ & $\mathrm{m}$ & $\mathrm{u}$ \\
\hline Price & 0.6749 & 1.1914 & 1.9245 \\
\hline Fragrant & 0.5493 & 0.9980 & 1.8206 \\
\hline Contents & 0.3707 & 0.5806 & 1.0571 \\
\hline Quality & 1.9332 & 3.0171 & 4.2410 \\
\hline Packaging & 0.2938 & 0.4782 & 0.8011 \\
\hline Amount & 3.8218 & 6.2653 & 9.8443 \\
\hline
\end{tabular}

3.4.2.6. The Sum of Each Side of the

\section{Geometric Mean}

Table 7. The process of adding each side of the geometric mean

\begin{tabular}{|l|c|c|c|c|c|c|}
\hline \multirow{2}{*}{ Criteria } & \multicolumn{3}{|c|}{ Amount } & \multicolumn{3}{c|}{ Amount } \\
\cline { 2 - 7 } & $\mathbf{I}$ & $\mathbf{m}$ & $\mathbf{u}$ & $\mathbf{l}$ & $\mathbf{m}$ & $\mathbf{u}$ \\
\hline Price & 0.675 & 1.191 & 1.925 & 0.262 & 0.160 & 0.102 \\
\hline Fragrant & 0.549 & 0.998 & 1.821 & 0.262 & 0.160 & 0.102 \\
\hline Contents & 0.371 & 0.581 & 1.057 & 0.262 & 0.160 & 0.102 \\
\hline Quality & 1.933 & 3.017 & 4.241 & 0.262 & 0.160 & 0.102 \\
\hline Packaging & 0.294 & 0.478 & 0.801 & 0.262 & 0.160 & 0.102 \\
\hline
\end{tabular}

At this point, one is multiplied by each middle, and topsides, and divided by the total of each geometric mean column. Table 7 illustrates this. geometric mean of each side, both the bottom, 
Table 8 shows the results of the computations resulting from the sum of each side of the geometric mean.

Table 8. The result of the calculation of the sum of each side of the geometric mean

\begin{tabular}{|l|c|c|c|}
\hline \multirow{2}{*}{ Criteria } & \multicolumn{3}{|c|}{ Si } \\
\cline { 2 - 4 } & $\mathrm{I}$ & $\mathrm{m}$ & $\mathrm{u}$ \\
\hline Price & 0.177 & 0.190 & 0.195 \\
\hline Fragrant & 0.144 & 0.159 & 0.185 \\
\hline Contents & 0.097 & 0.093 & 0.107 \\
\hline Quality & 0.506 & 0.482 & 0.431 \\
\hline Packaging & 0.077 & 0.076 & 0.081 \\
\hline
\end{tabular}

\subsubsection{Determination of Vector Value (V) and Defuzzification Ordinate Value $\left(D^{\prime}\right)$}

Using equation 4 , finding the vector value for each cell is carried out in this stage. If the value of $\mathrm{m} 2>=\mathrm{m} 1$, the vector value is 1 , but otherwise, the vector value is calculated using the equation. Finally, for each row, determine the lowest value of the vector value. Table 10 summarizes the findings.

Table 9. Determination of Vector Value (V) and Defuzzification Ordinate (D')

\begin{tabular}{|c|c|c|c|c|c|c|}
\hline \multicolumn{6}{|c|}{ Criteria Comparison } & \multirow{2}{*}{ W } \\
\hline & Price & Fragrant & Contents & Quality & Packaging & \\
\hline Price & & 0.21 & -2.45 & -6.84 & -5.11 & -6.84 \\
\hline Fragrant & 1.00 & & -1.20 & -8.16 & -3.02 & -8.16 \\
\hline Contents & 1.00 & 1.00 & & -6.06 & -21.13 & -21.13 \\
\hline Quality & 1.00 & 1.00 & 1.00 & & 22.09 & 1.00 \\
\hline Packaging & 1.00 & 1.00 & 1.00 & 1.00 & & 1.00 \\
\hline & & Amount & & & Amount & $-34,13$ \\
\hline
\end{tabular}

\subsubsection{Normalization}

After you have calculated the defuzzification value, you will need to normalize it by dividing the smallest defuzzification value (W) by the total defuzzification in the column.

Table 10. summarizes the findings.

\begin{tabular}{|c|c|}
\hline \multicolumn{2}{|c|}{ Normalization } \\
\hline Price & 0.200 \\
\hline Fragrant & 0.239 \\
\hline Contents & 0.619 \\
\hline Quality & -0.029 \\
\hline Packaging & -0.029 \\
\hline
\end{tabular}

Table 11. Conclusion and Ranking of Alternatives

\begin{tabular}{|c|c|c|}
\hline Alternative & Average & Rank \\
\hline Rinso & 1.043846 & 3 \\
\hline Daia & 1.596032 & 1 \\
\hline Jazz1 & 1.017579 & 4 \\
\hline So Klin & 1.476028 & 2 \\
\hline Attack & 0.470298 & 6 \\
\hline Surf & 0.352186 & 7 \\
\hline BOOM & 0.885856 & 5 \\
\hline
\end{tabular}

Compared to the other options, the alternative (Daia) has an ideal weight value of 1,596, as shown in the table above. As a result, it is safe to say that Daia is the most excellent detergent brand. On the 
other hand, the decision's outcome is merely a suggestion to help women make decisions.

\section{CONCLUSION}

It can be inferred from this study that using the fuzzy AHP approach to identify the best detergent brand can improve the target accuracy of the evaluated alternatives and the effectiveness of the assessment process from the central value input to the final value calculation. According to the idea, other strategies could be used to develop this research further.

\section{REFERENCES}

[1] Suppliers Using the Fuzzy Ahp and Topsis Method," J. Ilm. Tek. Ind., vol. 7, no. 1, pp. 70-78, 2019, doi: 10.24912/jitiuntar.v7i1.5037.

[2] V. Maarif, H. M. Nur, and T. A. Septianisa, "Decision Support System for Choosing the Right Skincare for Facial Skin Using Fuzzy Logic," EVOLUSI J. Sains dan Manaj., vol. 7, no. 2, pp. 73-80, 2019, doi: 10.31294/evolusi.v7i2.6755.
[3] Jasril, E. Haerani, and L. Afrianty, "Decision Support System (SPK) Selection of the Best Employees Using the Fuzzy Ahp (F-Ahp) Method," in Seminar Nasional Aplikasi Teknologi Informasi 2011 (SNATI 2011), 2011, vol. 2011, pp. 36-43.

[4] D.-Y. Chang, "European Journal Of Operational Research Applications of the extent analysis method on fuzzy AHP," Eur. J. Oper. Res., vol. 95, no. 95, pp. 649-655, 1996.

[5] F. S. Apriliana and B. Suhardi, "Selection of Lamps in the Library Lighting System Using the Fuzzy AHP Method," Tekinfo J. Ilm. Tek. Ind. dan Inf., vol. 9, no. 2, pp. 146-158, 2021, doi: 10.31001/tekinfo.v9i2.848.

[6] S. H. Lee, "Using fuzzy AHP to develop intellectual capital evaluation model for assessing their performance contribution in a university," Expert Syst. Appl., vol. 37, no. 7, pp. 4941-4947, 2010, doi: 10.1016/j.eswa.2009.12.020. 